\title{
UTJECAJNE LINIJE KONSTRUIRANE PROGRAMOM AUTODESK ROBOT
}

\author{
Silva Lozančić \\ Sveučilište Josipa Jurja Strossmayera u Osijeku, Građevinski fakultet Osijek, prof.dr.sc. \\ Marin Grubišić \\ Sveučilište Josipa Jurja Strossmayera u Osijeku, Građevinski fakultet Osijek, mag.ing.aedif. \\ Tomislav Bakunić \\ Sveučilište Josipa Jurja Strossmayera u Osijeku, Građevinski fakultet Osijek, student
}

\begin{abstract}
Sažetak: Utjecajne funkcije i njihov grafički prikaz - utjecajne linije, koriste se kod proračuna konstrukcija izloženih djelovanju pokretnih opterećenja. Njima se određuje položaj pokretnog opterećenja koji će dati najnepovoljnije utjecaje na konstrukciju (maksimalne unutarnje sile i pomake) ili njezine dijelove. Cilj ovog rada je analizirati utjecajne linije statički određenih i neodređenih sustava dobivenih programskim paketom Autodesk Robot Structural Analysis, te in usporediti s jednakima, dobivenima analitičkim putem. U novije vrijeme računala su postala nezamjenjivi alat svakom inženjeru u praksi, no ipak je potrebno dobivene numeričke rezultate raznim programskim paketima prihvatiti uz oprez, te proučiti ograničenja svakog programa. Na nekoliko jednostavnih primjera statički određenih i neodređenih sustava proučene su utjecajne linije dobivene programskim paketom Autodesk Robot Structural Analysis, te uočena dobra podudarnost rješenja s analitičkim rezultatima. Sve dobivene pogreške tijekom rada mogu se generalizirati i korigirati ulaznim parametrima programa, a rezultate dobivene ovim putem možemo koristiti u statičkim proračunima konstrukcija.
\end{abstract}

Ključne riječi: utjecajne linije, statički određeni i neodređeni sustavi, Autodesk Robot Structural Analysis

\section{INFLUENCE LINES CONSTRUCTED USING AUTODESK ROBOT}

\begin{abstract}
Influence functions and their graphical representation - influence lines are used in calculation of structures exposed to moving loads. They are used to determine the position of the moving load that will give the most adverse impacts of construction or its components (maximum internal forces, deflections and displacements), and to determine the values of these quantities. The aim of this work is to analyse influence lines of statically determined and indetermined systems obtained by software, and compare them with the same obtained by analytic methods. In recent years, computers have become an indispensable tool to every engineer in practice, and it is necessary to accepted numerical results obtained by various applications with exceptional caution, and also study the possible limitations of some software. A few examples of statically determined and indetermined systems are studied influence lines obtained software package Autodesk Robot Structural Analysis and observed a good correlation with the analytical results. The resulting operating errors can be generalized and corrected by the input parameters of the program, so the results can be used for static analysis of structures.
\end{abstract}

Key words: influence lines, statically determinate and indetermined systems, Autodesk Robot Structural Analysis 


\section{Uvod}

Neke konstrukcije, poput mostova, nadvožnjaka ili kranskih staza, preuzimaju opterećenja koja se kreću pokretna opterećenja, kao što su cestovna vozila, vlakovi ili kranovi. Promjenom položaja opterećenja na nosaču, mijenjaju se vrijednosti unutarnjih sila i pomaka u nosačima. Inercijalne sile, koje mogu nastati na nosaču ako se opterećenja kreću većim brzinama (za koje, radi pojednostavljenja, pretpostavljamo da nisu velike), mogu se zanemariti u proračunu jer su proporcionalne ubrzanjima.

Određivanje reakcija, unutarnjih sila i pomaka za pokretna opterećenja radi se konstruiranjem utjecajnih funkcija i njihovog grafičkog prikaza - utjecajnih linija za djelovanje jedinične koncentrirane sile koja se kreće po nosaču. Funkcija položaja jedinične sile koja se kreće po nosaču i čija je vrijednost iznos određene statičke ili geometrijske veličine izazvane tom silom na odabranom mjestu na nosaču, naziva se utjecajnom funkcijom za tu veličinu. Utjecajna funkcija svakom položaju jedinične sile na nosaču pridružuje vrijednost tom silom izazvane unutarnje sile ili pomaka u nekoj točki nosača. Utjecajna linija je grafički prikaz utjecajne funkcije na linijskim nosačima, dok je utjecajna ploha grafički prikaz na plošnim nosačima. Jedinična sila koja se kreće na nosaču kod traženja utjecajnih linija je bezdimenzionalna veličina.

Ako je pri djelovanju jedinične sile $u$ točki $x_{1}$ vrijednost određene sile ili pomaka $\eta_{1}$, tada će prema principu superpozicije, pri djelovanju sile $P_{1} u x_{1}$ vrijednost te veličine biti $P_{1} \cdot \eta_{1}$. Za dobivanje stvarnih reakcija unutarnjih sila od pokretnih opterećenja, ove vrijednosti utjecajnih linija, dobivene jediničnom silom, množe se $s$ vrijednostima pokretnog opterećenja danih propisima.

Utjecajne linije mogu biti linearne funkcije ili krivulje. Za statičke veličine na statički određenim nosačima utjecajne linije su linearne funkcije, dok na statički neodređenim nosačima su to krivulje. Pronalaze se statičkim ili kinematičkim metodama. Statički postupak se temelji na postavljanju jednadžbi ravnoteže iz kojih se dobivaju odgovarajuće veličine kao funkcije položaja jedinične sile. Kinematički postupak se temelji na principu virtualnih pomaka. Utjecajnu liniju poistovjećujemo i crtamo kao plan pomaka mehanizma nastalog raskidanjem veze koja u izvornom sustavu prenosi dotičnu silu, ako zadamo jedinični pomak na mjestu i u suprotnom smjeru od djelovanja te sile. Za statički neodređeni sustav, raskidanjem odgovarajuće veze dobivamo sustav koji je geometrijski nepromjenjiv, te crtamo njegovu progibnu liniju.

Utjecajne linije se najčešće određuju za statičke veličine: reakcije i unutarnje sile. Tražimo mjesto opterećenja na konstrukciji koje će prouzročiti maksimalan učinak na nosaču (u obliku maksimalnih reakcija, unutarnjih sila, pomaka). Postoje pravila za konstruiranje utjecajnih linija kao i kod konstruiranja dijagrama unutarnjih sila. Pravila nisu ista, jer i značenja dijagrama unutarnjih sila i utjecajnih linija nisu ista. Utjecajne linije pokazuju promjenu unutarnje sile u jednoj točki nosača, ovisno o položaju pokretnog opterećenja.

Utjecajne funkcije su u općenitom obliku funkcije dviju varijabli. Jedna varijabla je mjesto na nosaču u kojem se želi odrediti neka veličina, a druga je položaj jediničnog opterećenja. U praktičnim proračunima se mjesto tražene veličine unaprijed zadaje, te je stoga utjecajna funkcija funkcija jedne varijable, položaja jediničnog opterećenja. Za konstrukciju utjecajnih linija u programskom paketu Autodesk Robot potrebno je prvo definirati pokretno opterećenje - zadavanjem vozila i njegove putanje kretanja po konstrukciji. Program nudi određene tipove vozila koje ima u svojoj bazi podataka prema određenim standardima. Za prikazane primjere opterećenje je definirano jediničnom pokretnom koncentriranom silom, kao u analitičkom proračunu. Putanja nosača je cijeli nosač na čijoj duljini se opterećenje kreće.

Rezultati dobiveni programskim paketom za slučaj pokretnog opterećenja mogu se prikazati na dva načina. Prva se metoda sastoji u prikazu rezultata statičkog slučaja za položaj pokretnog opterećenja, odabranog od strane korisnika. Pritom su dostupne opcije kojima se omogućava promjena položaja pokretnog opterećenja. Korisnik može pomicati opterećenje korak po korak ili se pak može poslužiti animacijom vozila i rezultata za pokretno opterećenje. Druga se metoda sastoji u prikazu promjena vrijednosti odabrane veličine u danoj točki, $s$ obzirom na kretanje opterećenja po konstrukciji - odnosno po zadanoj putanji. Koristili smo ovaj prikaz utjecajnih linija za odabrane veličine jer je istovjetan analitičkom proračunu.

Ako su zadana, uz pokretno, i neka druga opterećenja na nosaču (koncentrirane sile, kontinuirana opterećenja, momenti), ne dobiju se utjecajne linije programom, ono se mora raditi kao zasebno opterećenje. 


\section{Usporedba primjera izrađenih programom i analitičkim proračunom}

\subsection{Statički određeni sustavi}

Za primjere statički određenih sustava uzeti su Gerberov, rešetkasti i poduprti nosač. Da bi se provjerila točnost rezultata programa, izračunane su utjecajne linije za iste primjere analitičkom metodom. Na sljedećim slikama prikazani su usporedni rezultati utjecajnih linija za određene statičke veličine dobivene analitičkim putem kinematskom metodom i programom. Svi sljedeći crteži označavaju točnu proračunsku vrijednosti ordinata utjecajnih linija, s tim da isti crteži nisu nužno prikazani u mjerilu, odnosno u točnim odnosima.

\subsubsection{Gerberov nosač}

Gerberov nosač, za koji su rađene utjecajne linije, prikazan je na slici 1.

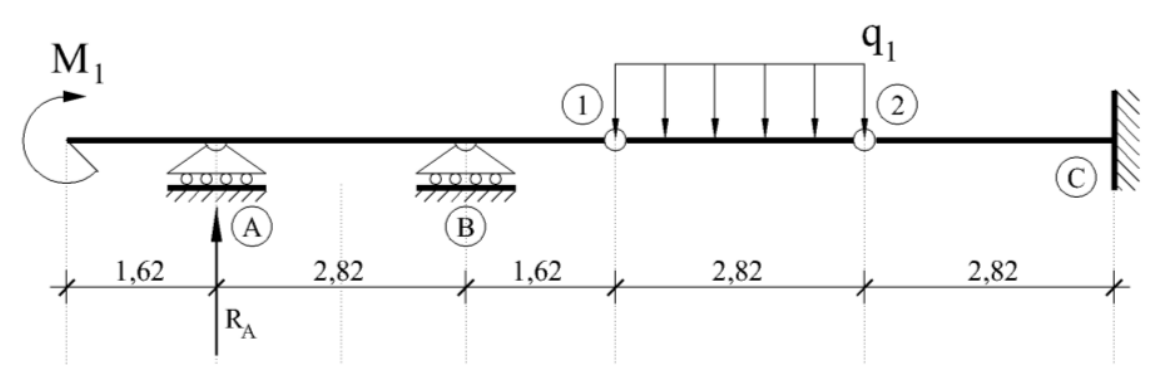

Slika 1 - Statički sustav Gerberovog nosača

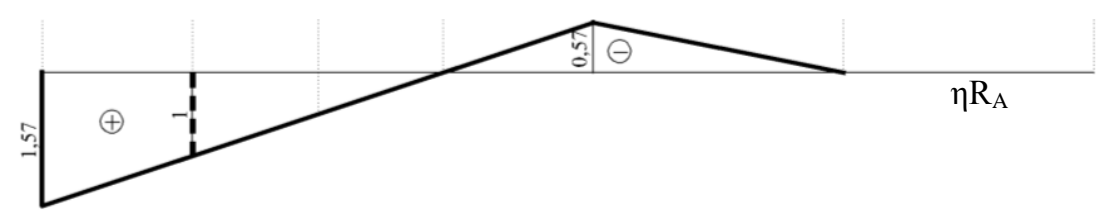

Slika 2 - Utjecajna linija riješena analitički za reakciju $R_{A}$ na Gerberovom nosaču

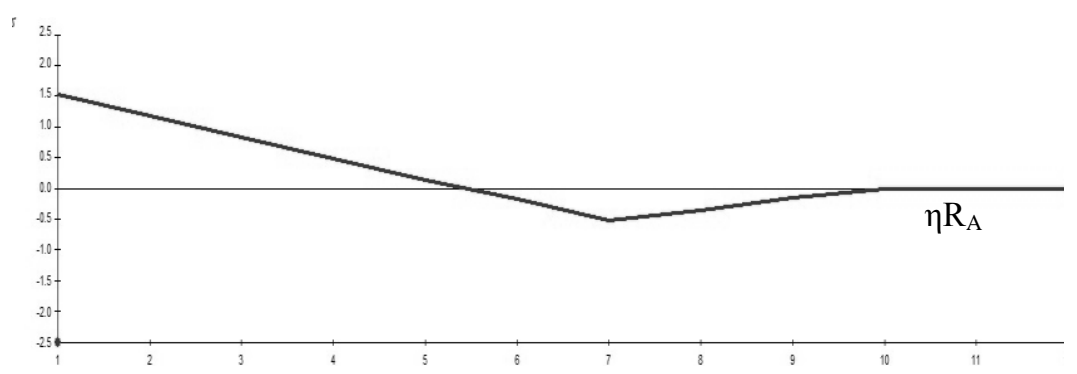

Slika 3 - Utjecajna linija riješena u Robotu za reakciju $R_{A}$ na Gerberovom nosaču 


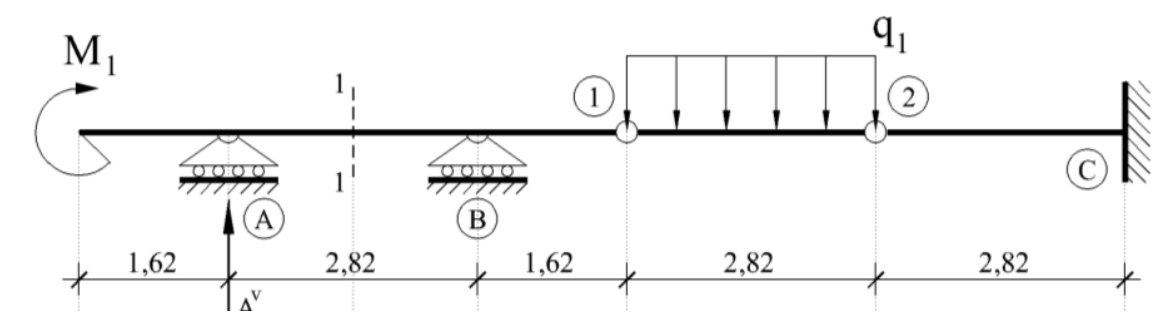

Slika 4 - Statički sustav Gerberovog nosača

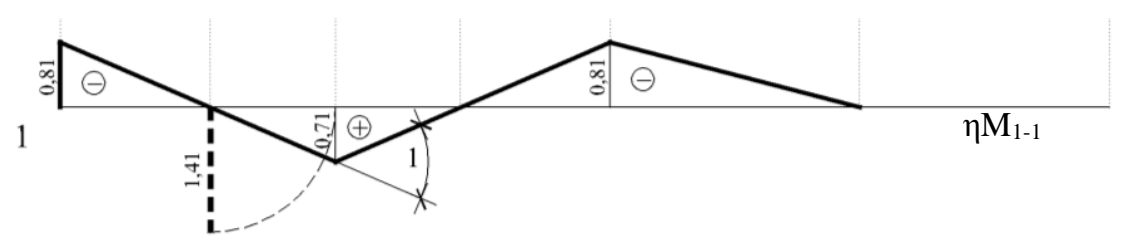

Slika 5 - Utjecajna linija riješena analitički za moment u presjeku 1-1 na Gerberovom nosaču

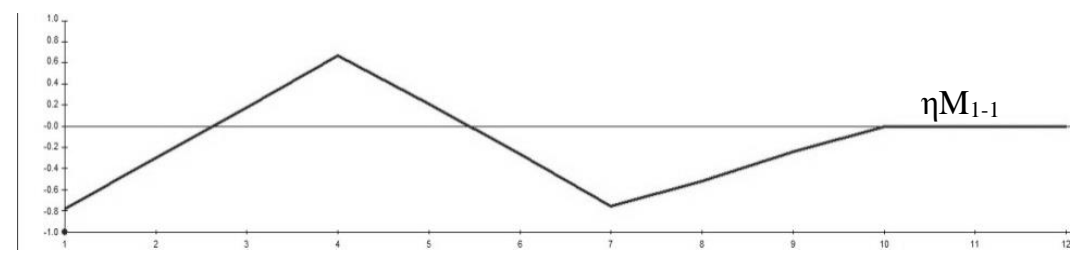

Slika 6 - Utjecajna linija riješena u Robotu za moment u presjeku 1-1 na Gerberovom nosaču

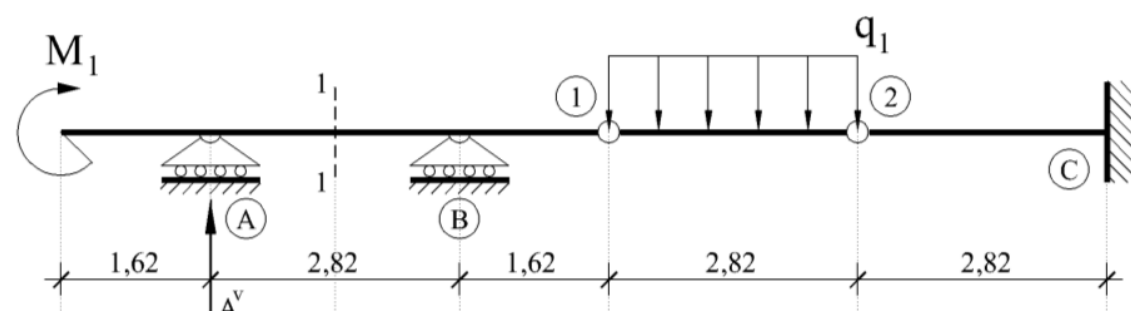

Slika 7 - Statički sustav Gerberovog nosača

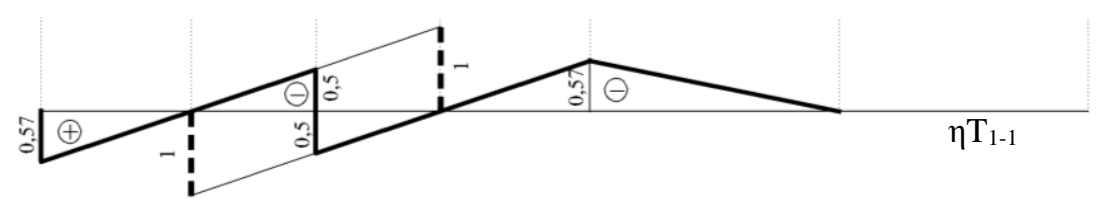

Slika 8 - Utjecajna linija riješena analitički za poprečnu silu u presjeku 1-1 na Gerberovom nosaču

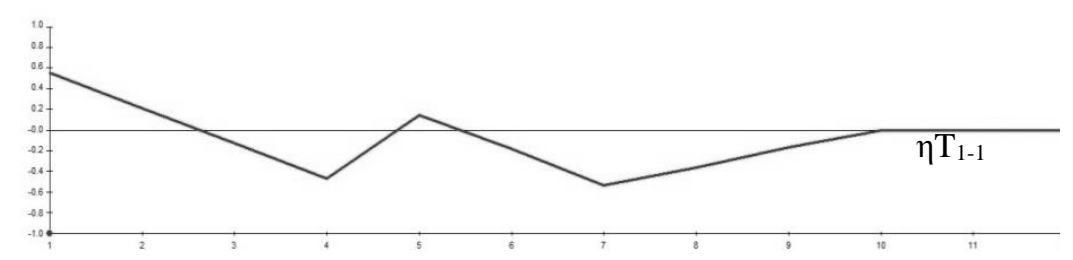


Slika 9 - Utjecajna linija riješena u Robotu za poprečnu silu u presjeku 1-1 na Gerberovom nosaču, korak $1,0 \mathrm{~m}$

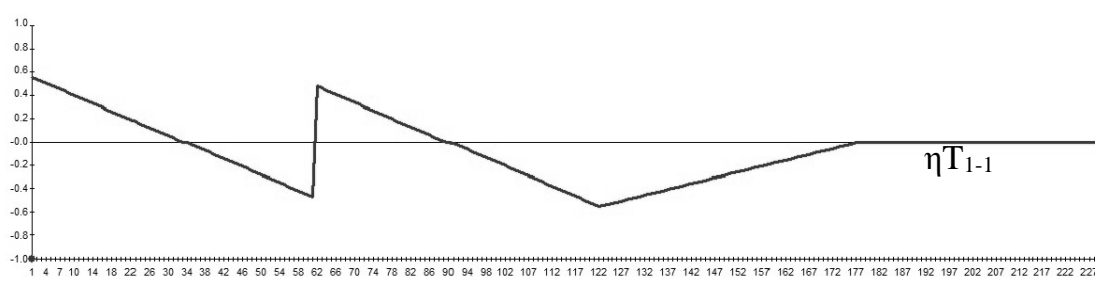

Slika 10 - Utjecajna linija riješena u Robotu za poprečnu silu u presjeku 1-1 na Gerberovom nosaču, korak 0,1 m

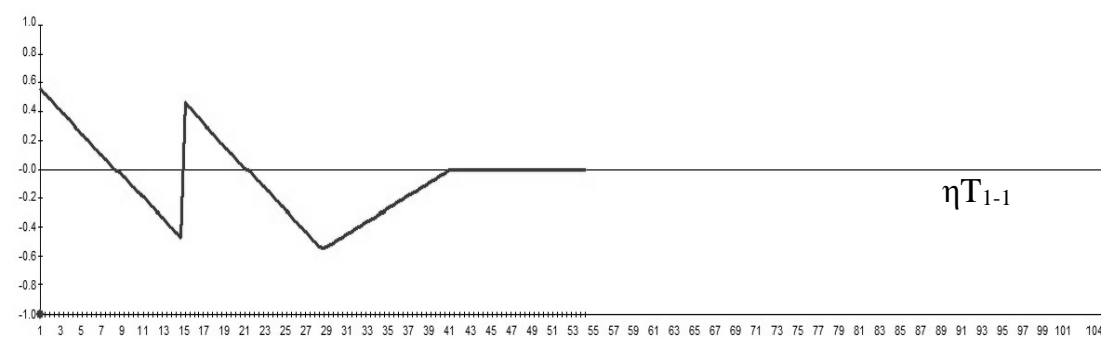

Slika 11 - Utjecajna linija riješena u Robotu za poprečnu silu u presjeku 1-1 na Gerberovom nosaču, korak 0,05 m

Iz riješenog primjera vidimo velikim dijelom podudaranje utjecajnih linija dobivenih analitičkim putem i programom, ali $\mathrm{i}$ neke razlike. Utjecajne linije dobivene programom Autodesk Robot prikazane su kao matematički prikaz graf funkcije. Predznak programom dobivenih utjecajnih linija za statički određene nosače suprotan je jednakima, dobivenima analitičkim putem.

Utjecajne linije za reakciju u ležaju i za moment u karakterističnom presjeku t-t jednake su, dobivene analitički ili programom. Do nepodudaranja dolazi kod utjecajnih linija za poprečne sile karakterističnog presjeka. Po pravilima konstruiranja utjecajnih linija, na mjestu nekog presjeka t-t, kada utjecajna linija ima skok u toj točki iz negativne u pozitivnu vrijednost ili obrnuto, suma obje vrijednosti jednaka je jediničnoj sili.

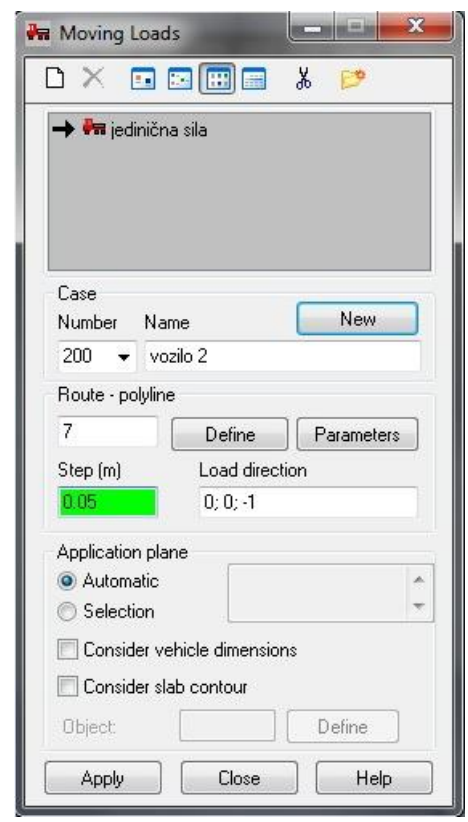




\section{Slika 12 - Izbornik pokretnog opterećenja u Autodesk Robotu}

Na utjecajnoj liniji poprečnih sila dobivenih Autodesk Robotom, na mjestu zadanog presjeka kao da je linija skoka zarotirana te je razvukla dio dijagrama utjecajne linije. Na mjestu presjeka nije se dogodio skok, nego lom. $\mathrm{Na}$ ostalom dijelu nosača utjecajna linija je podudarna.

Razlog tomu je loše zadan jedan ulazni podatak, na slici 2 je pokazan izbornik Autodesk Robota kojim se zadaje pokretno opterećenje. Kod definiranja opterećenja zadaje se korak (step) pomicanja opterećenja. Polazno je uzet korak $1 \mathrm{~m}$ i dao je loše rezultate za T silu, ostali su rezultati podudarni. Izmjenom koraka kretanja opterećenja na 0,1 m ili 0,05 m dobili smo podudaranje utjecajnih linija T sile.

\subsubsection{Rešetkasti nosač}

Kod rešetkastih nosača prema [3] zadano je da se opterećenje kreće po donjim štapovima pojasa, između ležajeva A i B. Utjecajne linije analitičkim putem su riješene statičkom Ritterovom metodom.

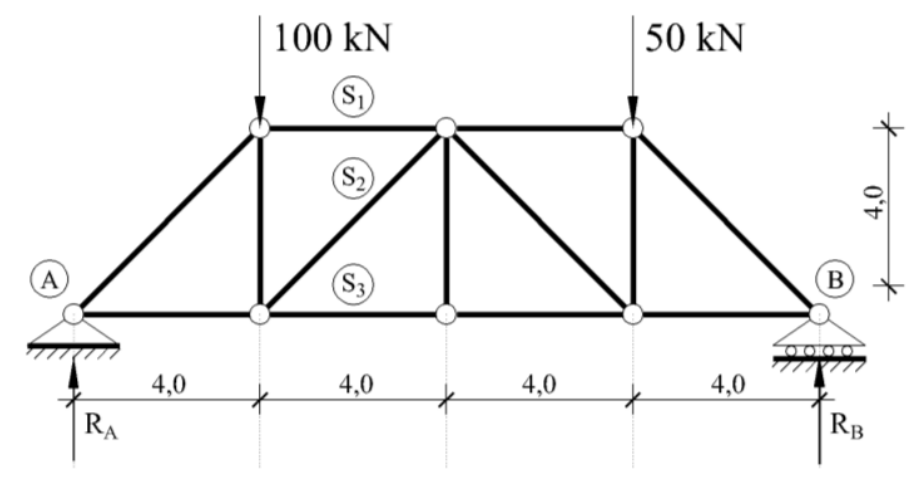

Slika 13 - Statički sustav rešetkastog nosača

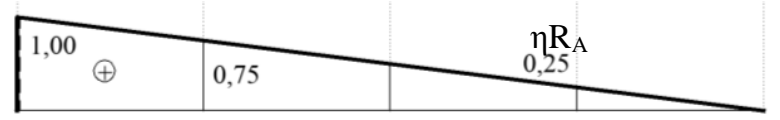

Slika 14 - Utjecajna linija riješena analitički za reakciju $R_{A}$ na rešetkastom nosaču

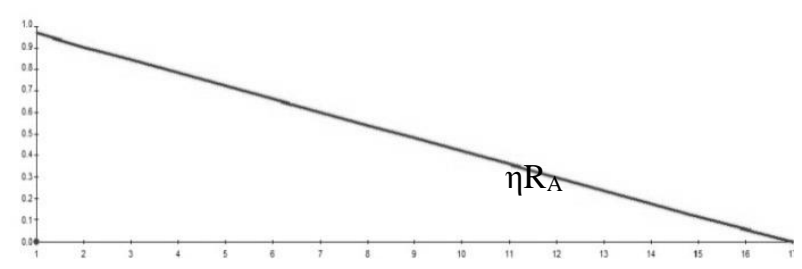

Slika 15 - Utjecajna linija riješena u Robot-u za reakciju $R_{A}$ na rešetkastom nosaču 


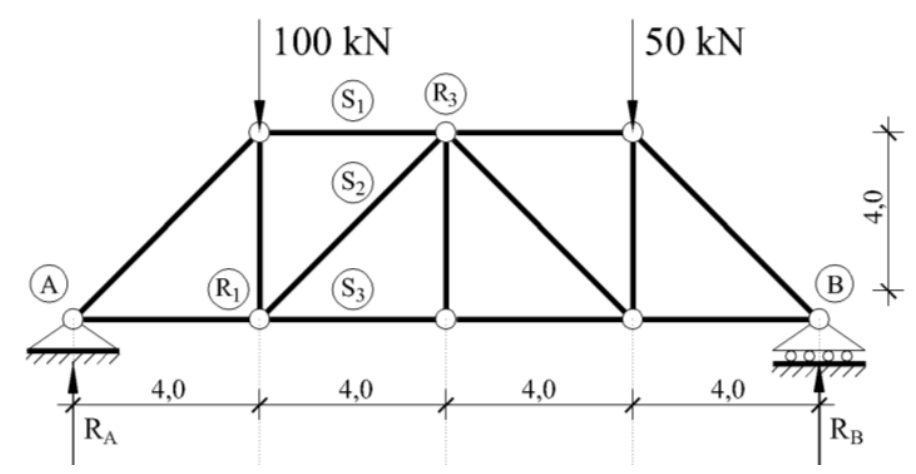

Slika 16 - Statički sustav rešetkastog nosača

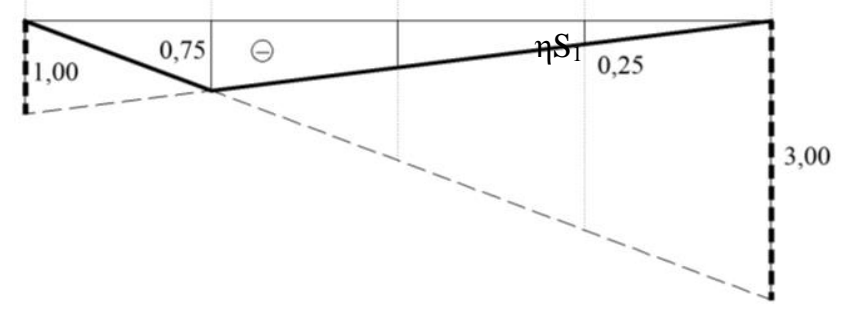

Slika 17 - Utjecajna linija riješena analitički za štap $S_{1}$ na rešetkastom nosaču

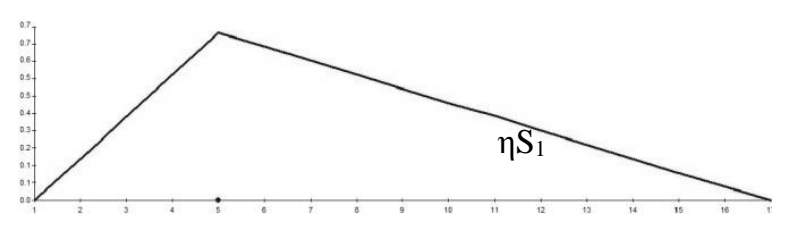

Slika 18 - Utjecajna linija riješena u Robotu za štap $S_{1}$ na rešetkastom nosaču

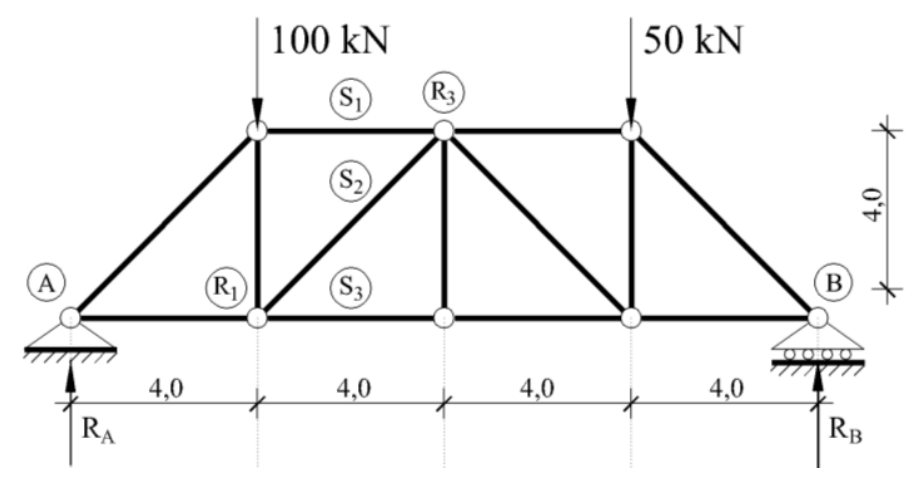

Slika 19 - Statički sustav rešetkastog nosača

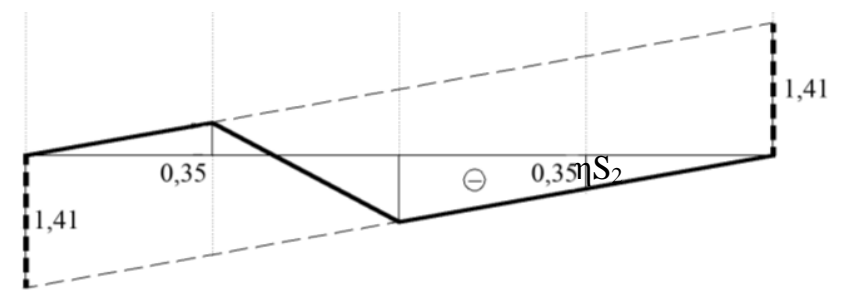

Slika 20 - Utjecajna linija riješena analitički za štap $S_{2}$ na rešetkastom nosaču 


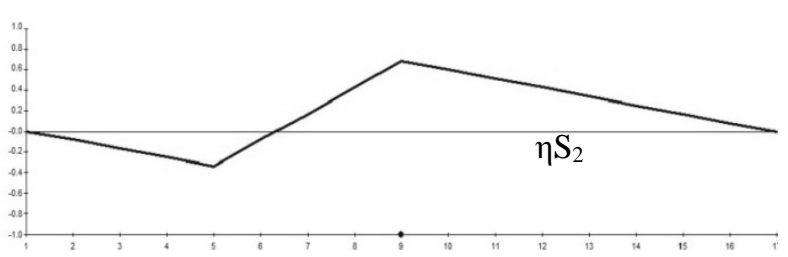

Slika 21 - Utjecajna linija riješena u Robotu za štap $S_{2}$ na rešetkastom nosaču

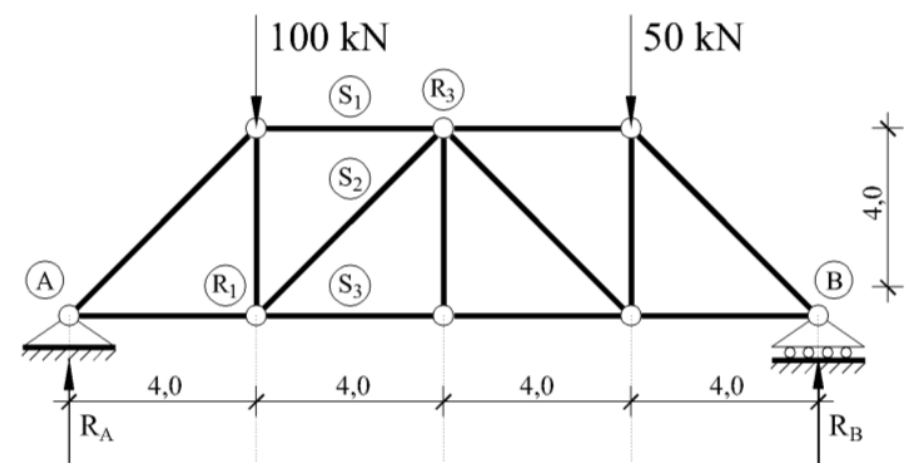

Slika 22 - Statički sustav rešetkastog nosača

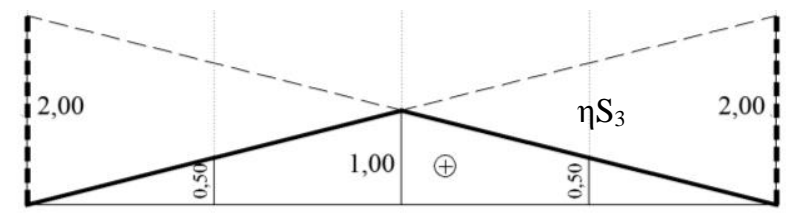

Slika 23 - Utjecajna linija riješena analitički za štap $S_{3}$ na rešetkastom nosaču

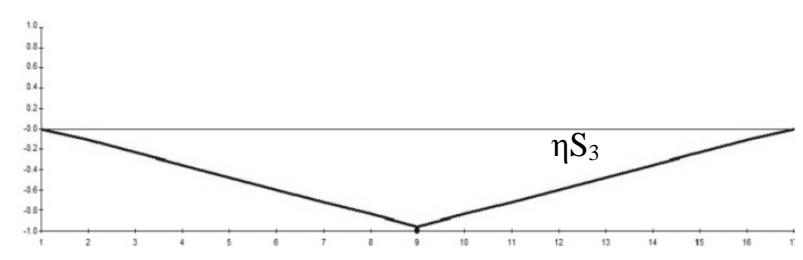

\section{Slika 24 - Utjecajna linija riješena u Robotu za štap $S_{3}$ na rešetkastom nosaču}

Iz usporedbe utjecajnih linija dobivenih analitičkim putem i programom Autodesk Robot, vidi se da nema nikakve razlike, i kod zadanog većeg koraka kretanja sile po nosaču od $1 \mathrm{~m}$, kakav je bio u ovom primjeru. Razlika je samo u predznaku utjecajne linije - suprotan je u ovim dvama postupcima dobivanja istih, za isto zadano opterećenje.

\subsubsection{Poduprta greda}

Kod složenog statički određenog sustava poduprte grede prema [10], pokazalo se potpuno poklapanje rezultata analitičkog i računalnog proračuna - i predznak utjecajnih linija je jednak. 


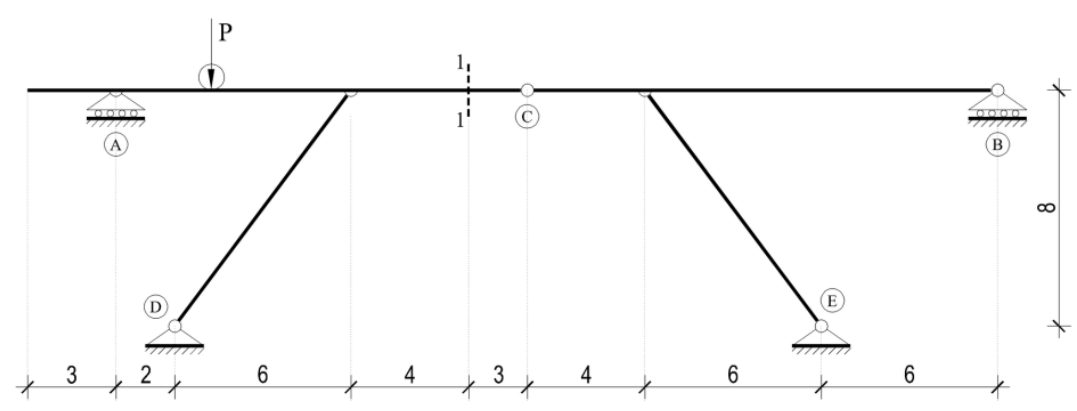

Slika 25 - Statički sustav poduprte grede

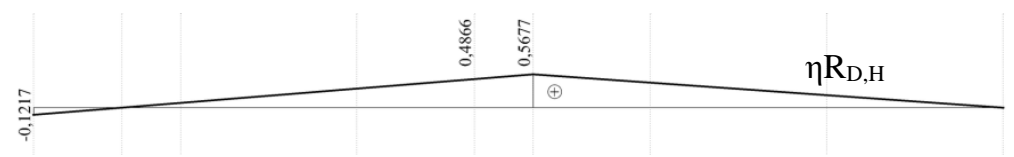

Slika 26 - Utjecajna linija riješena analitički za reakciju $R_{D, H}$ na poduprtoj gredi

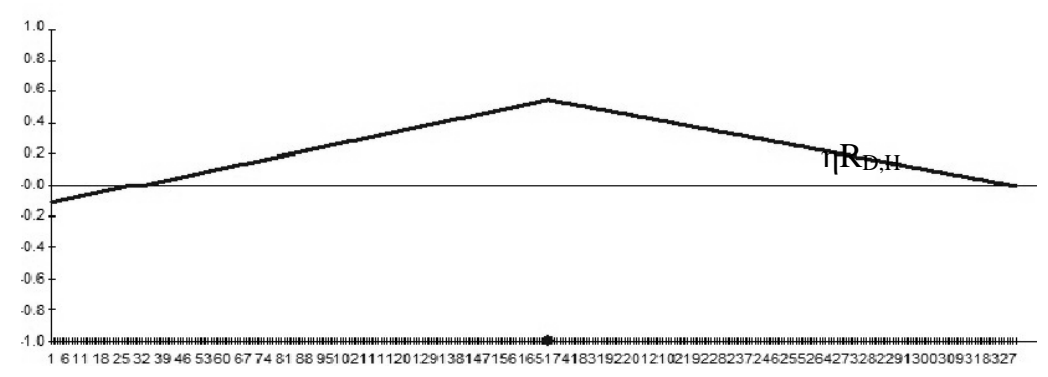

Slika 27 - Utjecajna linija riješena u Robotu za reakciju $R_{D, H}$ na poduprtoj gredi

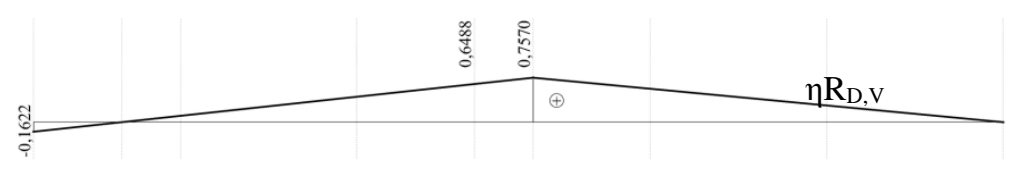

Slika 28 - Utjecajna linija riješena analitički za reakciju $R_{D, v}$ na poduprtoj gredi

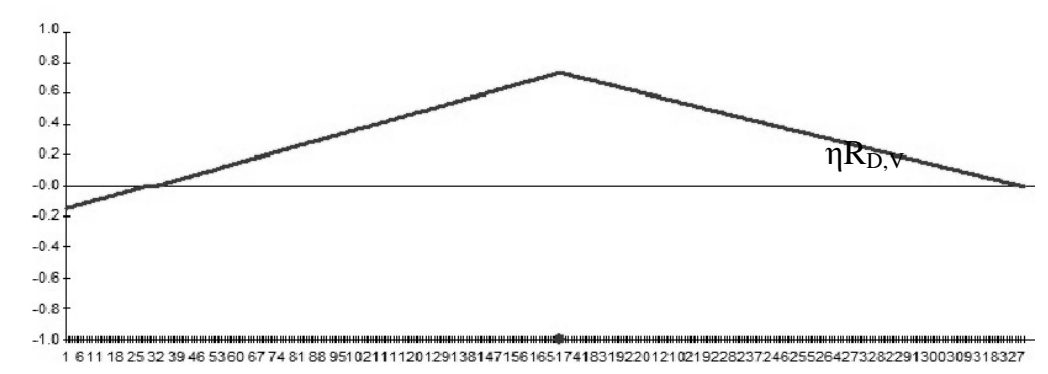

Slika 29 - Utjecajna linija riješena u Robotu za reakciju $R_{D, v}$ na poduprtoj gredi 


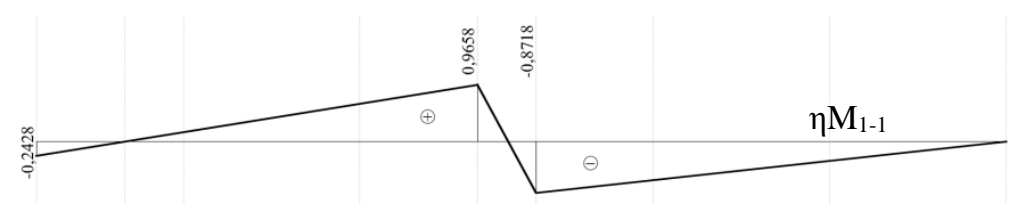

Slika 30 - Utjecajna linija riješena analitički za moment u presjeku 1-1 na poduprtoj gredi

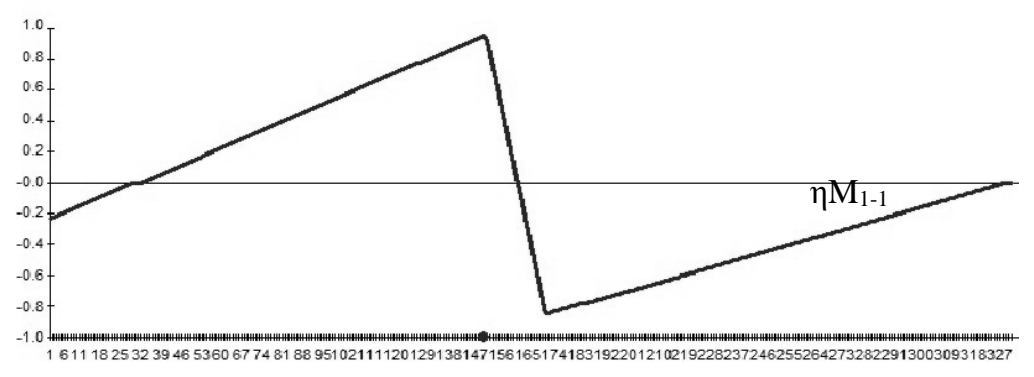

Slika 31 - Utjecajna linija riješena u Robotu za moment u presjeku 1-1 na poduprtoj gredi

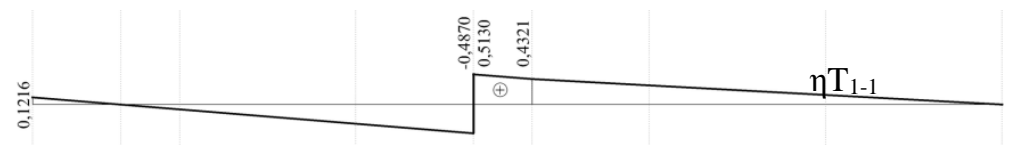

Slika 32 - Utjecajna linija riješena analitički za poprečnu silu u presjeku 1-1 na poduprtoj gredi

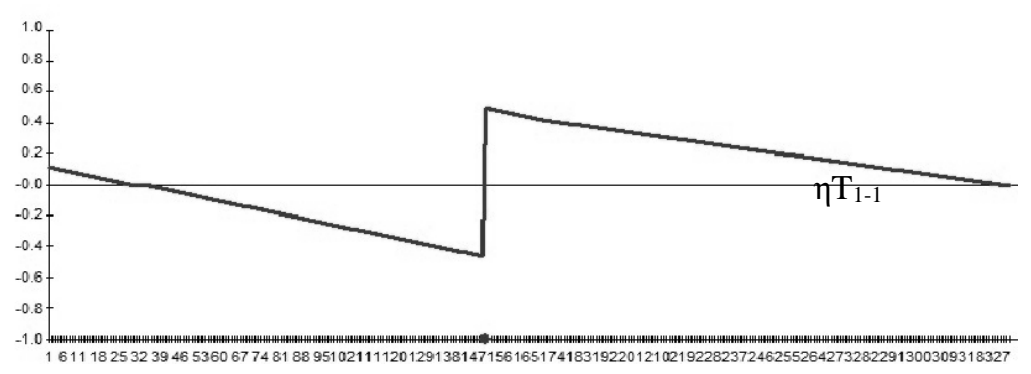

Slika 33 - Utjecajna linija riješena u Robotu za poprečnu silu u presjeku 1-1 na poduprtoj gredi

\subsection{Statički neodređeni sustav}

\subsubsection{Kontinuirani nosač}

Postupak definiranja nosača, pokretnog opterećenja i dobivanja utjecajnih linija programom za statički neodređen sustav, nimalo se ne razlikuje od postupka kod statički određenih nosača. Kod njih je bitno zadati manji korak kretanja opterećenja jer se pri većem koraku kretanja dobiju utjecajne linije kao linearizirani pravci, što je vidljivo 
na slici 38. Utjecajne linije statički neodređenih sustava su krivulje. Također se pri većem koraku, umjesto skoka u promatranom presjeku za utjecajnu silu T, u programom dobivenoj utjecajnoj liniji događa lom. Izborom manjeg koraka dobiju se dobre utjecajne linije. Kod ovoga nosača podudaraju se predznaci utjecajnih linija.

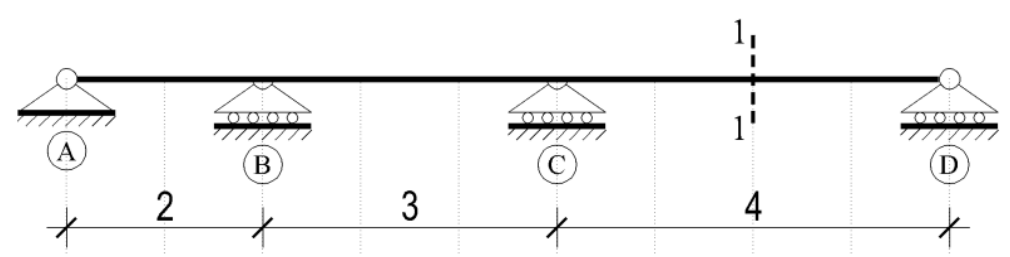

Slika 34 - Statički sustav kontinuiranog nosača

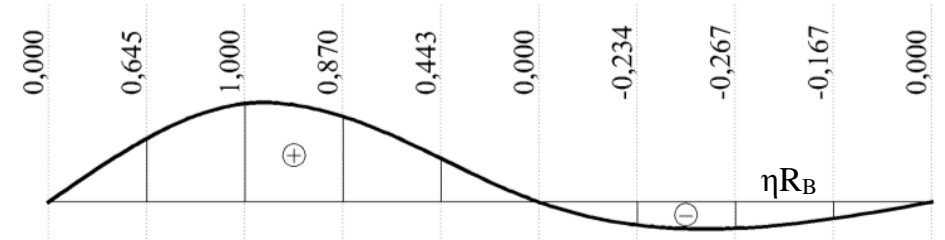

Slika 35 - Utjecajna linija riješena analitički za reakciju $R_{B}$ na kontinuiranom nosaču

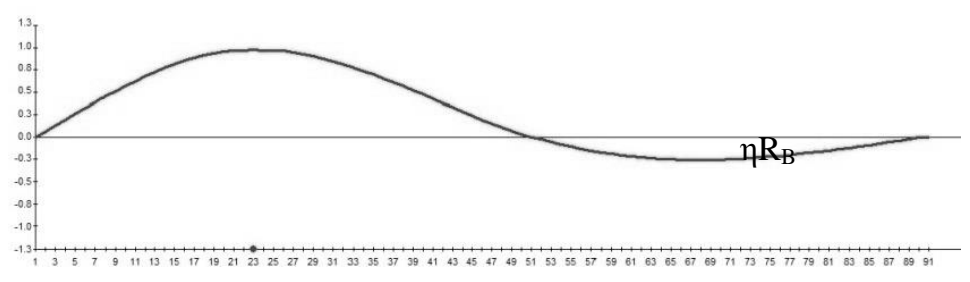

Slika 36 - Utjecajna linija riješena u Robotu za reakciju $R_{B}$ na kontinuiranom nosaču

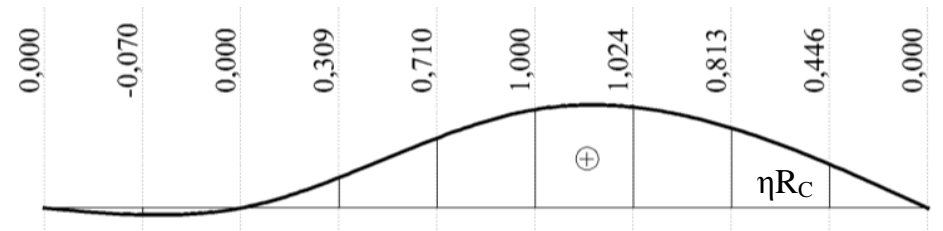

Slika 37 - Utjecajna linija riješena analitički za reakciju $R_{c}$ na kontinuiranom nosaču

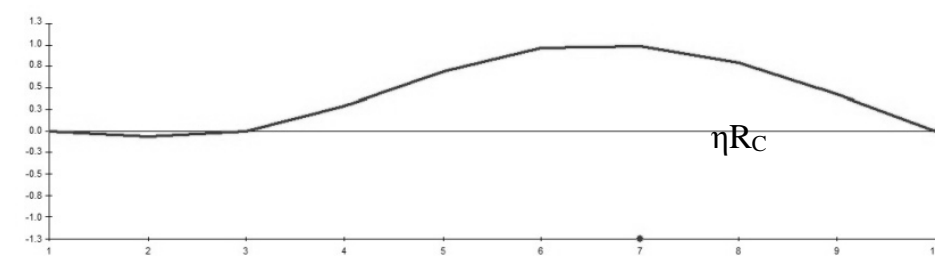

Slika 38 - Utjecajna linija riješena u Robotu za reakciju $R_{c}$ na kontinuiranom nosaču, korak 1,0 m 


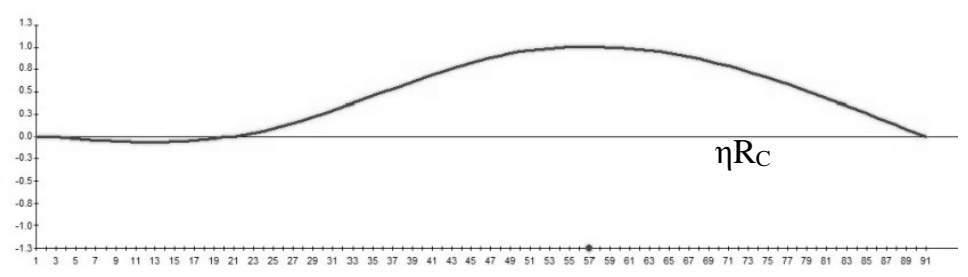

Slika 39 - Utjecajna linija riješena u Robotu za reakciju $R_{B}$ na kontinuiranom nosaču, korak 0,1 m

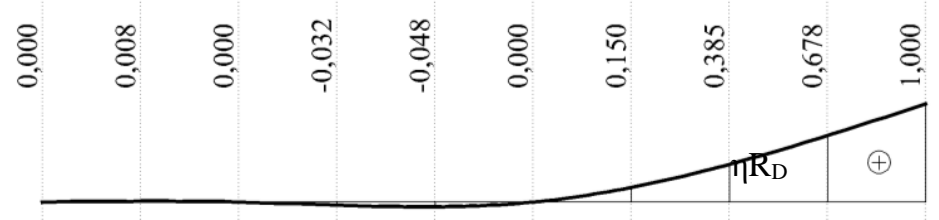

Slika 40 - Utjecajna linija riješena analitički za reakciju $R_{D}$ na kontinuiranom nosaču

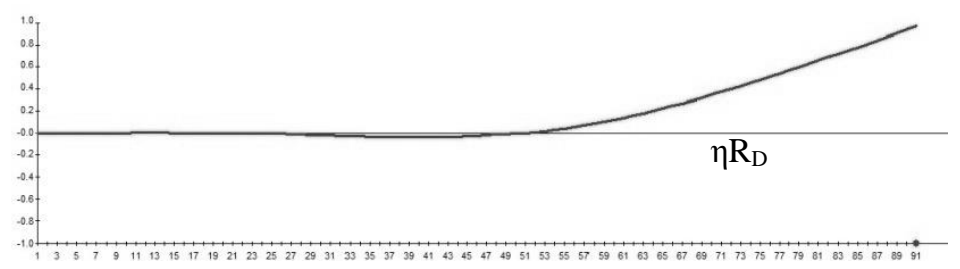

Slika 41 - Utjecajna linija riješena u Robotu za reakciju $R_{D}$ na kontinuiranom nosaču

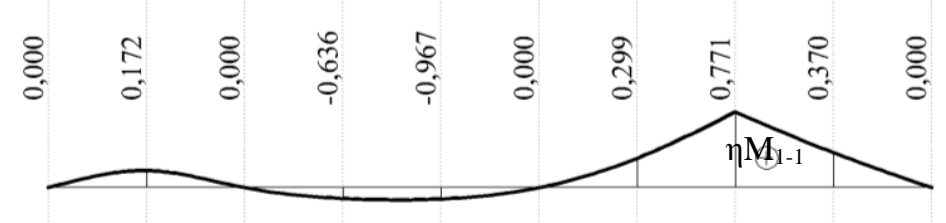

Slika 42 - Utjecajna linija riješena analitički za moment u presjeku 1-1 na kontinuiranom nosaču

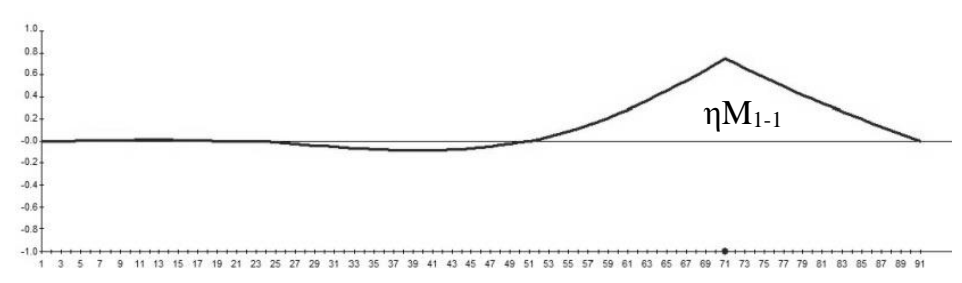

Slika 43 - Utjecajna linija riješena u Robotu za moment u presjeku 1-1 na kontinuiranom nosaču

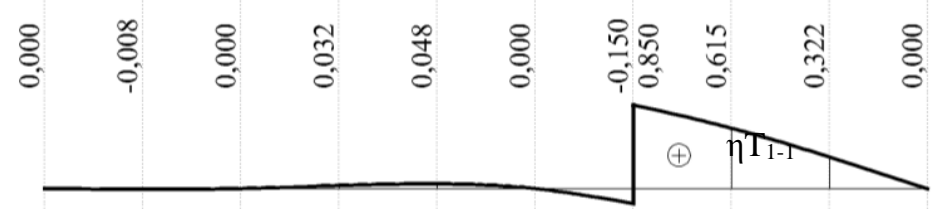




\section{Slika 44 - Utjecajna linija riješena analitički za poprečnu silu u presjeku 1-1 na kontinuiranom nosaču}

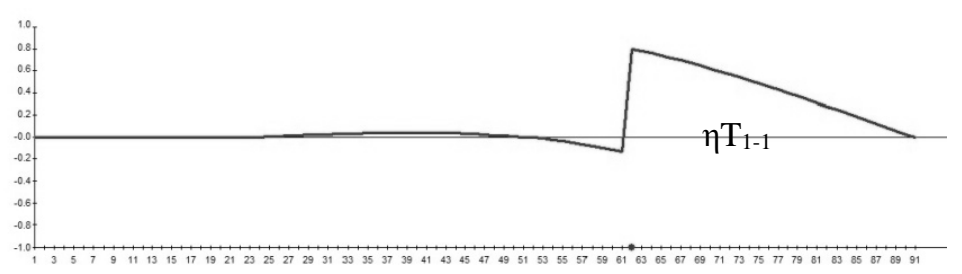

\section{Slika 45 - Utjecajna linija riješena u Robotu za poprečnu silu u presjeku 1-1 na kontinuiranom nosaču}

„Nedostatak“ utjecajnih linija dobivenih programom Autodesk Robot je njihov prikaz u obliku grafa na kojemu se ne ispisuju vrijednosti ordinate u vrhovima. Uz graf, program daje i prateću tablicu u kojoj su ispisane sve vrijednosti apscisa i ordinata ove graf funkcije, te se one tu mogu naći. Sve vrijednosti su podudarne do na 1. decimalu, kada je korak manji i na 2 . decimalu. Kod statički neodređenih nosača utjecajne linije se podudaraju i po predznaku, kao i za složenije statički određene sustave.

\section{Zaključak}

Utjecajne linije se koriste za određivanje dijagrama unutarnjih sila i pomaka od pokretnog opterećenja na nosaču. $\mathrm{U}$ radu se htjelo pokazati kako se te linije konstruiraju korištenjem računalnog programa Autodesk Robot. To je najjednostavniji i najbrži način konstruiranja, a nije toliko obrađen u literaturi.

Da bi se ispitala mogućnost ovog programa u konstruiranju utjecajnih linija, napravljeno je nekoliko primjera programom i rezultati su uspoređeni s rezultatima analitičkog postupka. Rezultati utjecajnih linija su identični u oba postupka za sve napravljene primjere, izuzev predznaka istih.

Došlo je do nepodudaranja utjecajnih linija u svim primjerima za poprečne sile, na mjestu presjeka u kojem se tražila utjecajna linija dogodio se lom umjesto skoka, pri odabiru većeg koraka kretanja poprečne sile od $1 \mathrm{~m}$. Pri tom koraku su kod statički neodređenih nosača utjecajne linije dobivene kao linearizirani pravci, a ne krivulje. Smanjivanjem koraka dobivene su istovjetne utjecajne linije u oba postupka. Smanjen je korak na 0,1 m i 0,05 m. Korak $0,05 \mathrm{~m}$ daje bolje utjecajne linije poprečnih sila i vrijednosti malih ordinata, za razliku koraka od $0,1 \mathrm{~m}$ koji daje zadovoljavajuće rezultate.

Može se zaključiti da je postupak dobivanja utjecajnih linija u Autodesk Robotu brz i jednostavan, $s$ rezultatima koji su posve identični proračunskom načinu. Poznavajući ograničenja ovog programa u konstruiranju utjecajnih linija, te nedostatke možemo ispraviti i koristiti utjecajne linije dobivene programom. Uz to, ovaj postupak može koristiti i kao provjera analitičkog postupka. Ovakav način konstruiranja utjecajnih linija je puno brži i jednostavniji od klasičnih metoda i kao takav olakšava nam proračun utjecajnih linija, posebno kod složenijih statičkih sustava.

\section{Literatura}

[1] Autodesk ${ }^{\circledast}$ Robot $^{\text {Tw }}$ Structural Analysis Professional 2010, Training Manual - Metric Version, http://images.autodesk.com/adsk/files/robot_2010_training_manual_metric.pdf

[2] Fanous F.:Introductory Problems in Structural Analysis: Influence Lines. (April 20 th, 2000 ).

[3] Fresl K.: Građevna statika 1: bilješke i skice s predavanja, http://www.grad.hr/nastava/gs/bilj1/uf1.pdf (pokušaj pristupa 12.10.2012)

[4] http://www.engr.uky.edu/ gebland/CE\%20582/Nelson\%20\&\%20McCormick\%20Force\%20Method\%20ILD. pdf (pokušaj pristupa 12.10.2012)

[5] Kassimali A.: Structural Analysis, CL Engineering; 4 edition (March 3 ${ }^{\text {rd }}$, 2009), English

[6] Kharagpur: Structural Analysis, Version 2 CE IIT, (August $7^{\text {th }}, 2008$ ). 
[7] Leet K:: Fundamentals of Structural Analysis, McGraw-Hill Science/Engineering/Math; 4 edition (September $\left.9^{\text {th }}, 2010\right)$.

[8] Lozančić S.: Građevna statika 1, materijali za predavanja i vježbe; Građevinski Fakultet Osijek, http://www.gfos.unios.hr/portal/index.php/nastava/studij//sveucilisni-preddiplomski-studii/gradjevna-statikai.html (pokušai pristupa 15.10.2012)

[9] Punmia B. C.; Ashok K. Jain, Arun K. Jain: Theory of Structures, Laxmi Publications, (December 1st, 2005), English

[10] Ribarić D., Građevna statika 1, materijali za predavanja i vježbe: http://www.gradri.hr/adminmax/files/class/Studentski\%20rad\%204.pdf (pokušaj pristupa 12.11.2012)

[11] Russell C., Hibbeler: Structural Analysis (7th Edition), Pearson Education Canada; 7 edition (May 5 ${ }^{\text {th }}, 2008$ ), English

[12] Timoshenko S. P., D. H. Young: Theory of Structures, $2^{\text {nd }}$ Edition, McGraw-Hill Book Company, inc. (1945).

[13] Simović V.: Građevna statika I, Građevinski institut, Zagreb, 1988. 